pedagogical support of instructional design at different levels of school education: content, methods and learning technologies, as well as designing learning environment and learning tools. Teaching practice proves that implementation of any innovation project requires both psychological and pedagogical support. The latter provides conditions for professional growth and commitment to implement innovative educational technologies into the educational process. It should be mentioned that competence approach is very important in instructional design. The new concept of Ukrainian national education is now being built basing on this approach. On the one hand, the structure of educational project in its psychological vision is considered to be associated with the presence of its performers' main competencies, and on the other hand, it can contribute effectively to their formation. Psycho-pedagogical aspects of instructional design are revealed in terms of including all components that influence the sequence and nature of the project participants. Specifically, it refers to the complex psychological and pedagogical analysis and diagnostics, systematic and comprehensive analysis and predicting, developing tasks for personal development, design, creating story line projects, developing project plans, designing personality-developing projects, etc.

Keywords: instructional design, competence approach, psychological and pedagogical support.

Реиензент: д. психол. н., проф. Л. А. Найдьонова

Подано до редакиії 03.02.2017

UDC: $159.944 .4: 37.011-051$

DOI: https://doi.org/10.24195/2414-4665-2017-3-3

Tetiana Dziuba,

PhD (Candidate of Psychological Sciences), associate professor, Department of General, Age and Practical Psychology Poltava National V.G. Korolenko Pedagogical University, 2, Ostrohradskoho Str., Poltava, Ukraine

\title{
IMPACT OF INTENSIVE DAILY STRESS ON TEACHER'S OCCUPATIONAL HEALTH
}

The paper deals with the specific parameters of the influence of intensive daily stress on teacher's occupational health. A number of significant correlation relationships among the determined parameters are analysed. Special attention is paid to the fact that the main chronic illnesses of today arise from emotional sufferings, acute and chronic stress. On the basis of the determined relationships, the intensive daily stress is considered to be the specific feature of teacher's work, which can result in emotional burn-out and loss of employee's occupational health under the particular conditions. The intensive daily stress exhausts pedagogue's adaptive resources, forming the harmful effects of professional and personal deformations (cognitive, emotional, behavioural) and negatively affecting the mood changes and professional coping-behaviour. Professional stress activates almost all human coping-strategies. However, the increase of the frequency of using passive ("escape behaviour", "careful actions", "acceptance") and prosocial ("search for social support") coping-strategies in the situation of the long-lasting intensive stress is observed. The rare use of the strategies of "healthy" active coping, intended for constructive transformation of a situation, and dominance of passive strategies lead to the professional stress with chronic character, which results in asocial behaviour, involving violation of moral norms in the situations of professional communication. The determined strategies can be treated like behavioural factors of risk of employee's occupational health under the conditions of the long-lasting intensive stress.

Keywords: intensive daily stress, occupational health, employee's adaptive resource, coping-strategies, harmful effects of professional and personal deformations, emotional burn-out, behavioural factors of risk of employee's occupational health.

\section{Introduction}

Intensive daily stress is considered to be inevitable companion of teacher's work. The teaching profession is associated with the situations which directly or indirectly are accompanied by significant psychoemotional and intensive intellectual tension, high level of social responsibility, overloading of organs of speech, sight, etc. Longlasting influence of the mentioned factors causes the exhaustion of organism resources and changes of central coordinative mechanisms state that appears in the activation of stress-realizing and organism systems limitation and leads to the restriction of its adaptive abilities, which results in different illnesses development. The fact that the main chronic illnesses of today arise from the emotional sufferings, acute and chronic stress is considered to be highly pervasive.

According to L. Vasserman and M. Berebin, teaching profession belongs to the occupations of high risk in terms of health problems. Examination of pedagogues' health state shows that $89.3 \%$ of them have health problems at the level of pre-existing disease ("risk group"), and the features of nosologic pathologic lesions are found in $43.8 \%$ of them [2]. Thus, studying the particularities of intensive daily stress influence on the teachers' health is 
considered to be a very important issue nowadays.

The analysis of the recent publications on this subject shows that the study of different aspects of professional activity influence on teachers' health can be found in the papers of Ukrainian and foreign scientists. First of all, these are the issues of highly stressful character of teachers' work [11], description of mental and somatic health problems [2], studying risk factors of specialists' occupational health [4], examining the consequences of pedagogues' health problems such as syndrome of emotional burn-out, crisis of professional development, professional destructions and deformations [7], etc. However, unfortunately, the relationship between intensive professional stress and professional teachers' health still remains understudied.

Considering the problematic topicality, the paper aims to determine the specific parameters of intensive daily stress influence on pedagogues' occupational health and to study significant correlation relationships among the determined parameters.

\section{Methodology}

Examination of specific parameters of intensive daily stress impact on teachers' occupational health was conducted using the author's questionnaire "Risks of Occupational Health" [4]. The study sample involved 1803 respondents, wherein 374 men and 1429 women aged from 20 to 57 years (average age is 33 years). Representativeness of the sample was established with the randomized selection method. Unequal distribution of the sample is described as an objective factor, considering that the most employees in educational establishments are women. Mathematical calculations, provided below, were automatised with computer-aided software package for statistical data analysis "IBM SPSS Statistics 21".

\section{Discussion}

Professional stress is considered as unspecific organism reaction to the influence (physical or psychological) of professional environment that disturbs homoeostasis and becomes the source of potential professional psychological risks of specialists' occupational health.

According to the results of correlation analysis the relationships between the factor "intensive daily stress" and indicators of emotional burn-out (V. Boyko approach) have been found. Particularly, "psycho-traumatic experience" (,469**), "being cornered" (,452*), "anxiety and depression" $\left(, 786^{* *}\right)$ in phase "tension" $\left(, 511^{* *}\right)$, "inadequate emotional selective reaction" $\left(, 783^{* *}\right)$ and "reduction of professional responsibilities" $\left(, 453^{* *}\right)$ in phase "resistance" $\left(, 794^{* *}\right)$, "emotional alienation" $\left(, 635^{* *}\right)$, "depersonalisation" $\left(, 876^{*}\right)$, "psychovegetative and psychosomatic disorders" $\left(, 585^{* *}\right)$ in phase "exhaustion" $\left(444^{* *}\right)$ have been revealed. Therefore, almost all indicators of burn-out syndrome show the statistically significant correlations. This tendency determines that the intensive daily stress is a specific characteristic feature of teachers' work, a result of the impact of different professional stress factors, especially of interpersonal nature and is a risk of emotional burn-out and loss of employees' occupational health.

Also it is important to note the tendency of the relationship between intensive daily stress and the indicators of professional disadaptation (according to M. Dmitrieva): "emotional changes" $\left(, 694^{* *}\right)$, "particularities of some mental processes" (,559*), "fatigue feeling” (,643*) and "sleep cycle disruption" $(, 772 *)$. In other words, intensive daily stress in teaching profession disturbs adaptive abilities (resources) of pedagogues, forming harmful effects of their professional and personal deformation. E. Rudenskyi divides such effects into three groups: cognitive (related to thinking and consciousness), emotional (related to emotions, feelings, personal characteristics) and behavioural (equally related to cognitive and affective factors) [8]. The indicated effects of teachers' professional and personal deformation arise in the situations of intensive professional communication and appear to be "lack of emotions", disappearing of fineness of feelings and experiences, escalation of conflicts with the communication partners, indifference and estrangement from other's sufferings, loss of trust in one's own professional abilities, etc. Cognitive effects of intensive daily stress in teaching profession are manifested in the following symptoms: decreasing of attention focusing (observation strength decreases, consciousness hardly stays focused); increasing of distraction and frequency of mistakes (the chain of thoughts or words might be lost even in the middle of the sentence; made decisions become unreliable); decreasing of short-term and long-term memory (the volume of memory is decreased, recalling and understanding of even familiar objects weaken); increasing of illusions and disruption of thinking (estimation of professional reality becomes less effective, strength of objective critical approach decreases, thinking becomes confused and irrational). Emotional effects of excessive stress are manifested in the following symptoms: increasing physical and psychological tension (the decrease of the ability for muscle relaxation, well-being, and removing of anxiety); increasing sickly suspiciousness (imaginary maladies are added to real disorders, caused by occupational stress); weakening moral and emotional restrictions (inclination to self-protection; appearance of authoritarian tendencies may be observed in democratic employees); dramatic self-depreciation (the feeling of incompetence and inferiority develops). Behavioural effects are displayed at the level of sleep disorders, in other words difficulties in falling asleep or staying awake for more than 4 hours. Danger of the emergence of the determined effects in teaching profession relates to the fact that intensive daily stress impact on a teacher is accompanied by accumulation of different-type professional stress factors, which provoke the appearance of inadaptive (which temporary decrease the work effectiveness) and disadaptive (which fully block the performance of professional activity and require rehabilitation influence) psychophysical states. At the same time not only obviously harmful impacts of professional environment can act like stress factors, but also critical moments of everyday situations [1, 
p. 379]. According to A. Leonova, psychophysical states are always characterized by internal resources waste. As a result of professional tension such usual states like "mobilisation, emotional arousal, compensated fatigue and others" are formed that is considered to be a consistency and in fact they are not considered as sources of serious troubles. However, "excessively high price" of profession becomes a real threat of teacher's occupational health [5].

Besides, the level of behaviour energetic resource decreases as a result of fatigue feeling, so a teacher feels exhausted even in the beginning of a working day, is focused on real or imaginary diseases, etc. It confirmation are noticed at the level of statistically significant relationships between intensive daily stress and indicators of J. Ozawa's Health Test. Correlation tendencies "fatigue feeling" $\left(, 637^{*}\right)$ and "deep and good sleep" $\left(, 416^{* *}\right)$ are determined on the scale "bodily health" $(, 462 *)$, negative correlations are found on the scale "mental health" (, $\left.500^{* *}\right)$ by the indicators "clarity of thought and businesses" (-,496*), "good memory" $(-, 442 * *)$ and "good mood" $(-, 542 *)$, scale "spiritual health" $(-, 624 * *)$ shows tendencies of negative correlations as well by the indicator "desire for justice" (-,317**).

Besides, some negative correlations between intensive daily stress and indicators of WAM Questionnaire (Well-being-Activity-Mood) "mood" $(-, 716)$ and "wellbeing" $\left(-, 551^{*}\right)$ have been revealed. Found correlation tendencies show that intensive daily stress exhausts professional forces of a teacher, leads to excessive psychophysical tension with further forming of negative functional states, thereby creating preconditions for the development of emotional burn-out syndrome. The last provokes increasing of general pathologies among which are the following: cardiovascular diseases [3], syndrome of neuroemotional tension [9], metabolic syndrome [6] and others. Another noteworthy fact is that first of all teaching profession is associated with the acquiring and processing of big load of information that determines tension of sensory apparatus and activation of mental processes [1, p. 379]. In this aspect intensive long-lasting stress can prominently disturb cognitive and mnemonic activity of a teacher, negatively affect his/her mood and professional coping-behaviour.

Since professional coping-behaviour is a process that is changed as a result of stress development and depends on cognitive evaluation and personal resources of a teacher, we have performed the analysis of statistically significant correlation relationships between intensive daily stress and pedagogues' coping-behaviour strategies (techniques by N. Osuhova and N. Vodopyanova, E. Strachenkova, correspondingly). According to the obtained data, factor "intensive daily stress" positively correlates with the following coping-strategies: "careful actions" (,635*), "acceptance" $(, 977 *)$, "escape behaviour" (,387** and, $756^{* *}$, correspondingly). So, high intensity of professional stress comports with high indices of using passive coping-strategies by teachers. At the same time positive significant correlation relationships between intensive daily stress and prosocial copingstrategies are noticed: "search for social support" $(, 581 *$ and ,689** correspondingly) and "self-control" (,435**). On the other hand, decreasing of using strategies "manipulative actions" $(-, 712 * *)$, "impulsive actions" ($, 512 * *)$, "opposing overtaking" $(-, 614 * *)$, "asocial actions" $(-, 203 * *)$, which belong to indirect and disadaptive coping-strategies, is observed in the situation of the longlasting intensive stress. Coping-strategies "distancing" ($, 506 * *)$, "assertive actions" $(-, 507 * *)$, "positive revaluation" $\left(-, 610^{* *}\right)$ show also indirect statistically significant correlation relationships with the factor "intensive daily stress". The obtained data demonstrate that professional stress activates almost all coping-strategies. However, the increase of the frequency of using passive ("escape behaviour", "careful actions", "acceptance") and prosocial ("search for social support") coping-strategies is observed in the situation of the long-lasting intensive stress (teacher's work is characterized by chronic stress). Careful escaping behaviour is used to avoid the solving of the professional problems. Search for social support reveals the need for emotional softening of professional situation and the desire to adapt to it. This leads not to the solution of professional problems, but to their intensifying. At the same time negative emotions related to professional stress are not overcome, but are transformed into psychosomatic disorders [10]. So, the determined strategies can be treated like the behavioural factors of risk of teachers' occupational health under the conditions of long-lasting intensive stress.

Thus, the low frequency of using "healthy" active behavioural patterns is closely related to professional stress experience, which is confirmed by negative correlation relationships of assertive actions and positive transformation in the situation of professional stress. According to O. Turenko, the rare use of "healthy" active coping strategies, focused on the constructive transformation of a situation, and dominance of the passive strategies cause professional stress with chronic character which results in asocial behaviour, involving violation of moral norms in the situations of professional communication [11, p. 188]. At the same time the frequency of using indirect and asocial strategies ("manipulative actions", "opposing overtaking", "impulsive actions") decreases but the frequency of using prosocial behavioural models ("search for social support", "self-control") increases. Therefore, professional stress level increase activates the frequency of using passive coping-strategies, which are protective mechanisms of forming such professional deformations as authority, indifference, professional aggression in the situations of chronic emotional overload. The imbalance between the requirements of professional environment and teacher's adaptive abilities requires mobilisation at all levels of organism functioning in order to support psychical homoeostasis and preserve the integrity of professional ego.

\section{Conclusions}

The carried out research has shown that intensive stress in teacher's work determines the changes, which directly or indirectly disrupt the balance of his/her life. 
Long-lasting experiencing of stress and intensive influence of professional environment stress-factors can lead to emotional and somatic disorders: psychosomatic and vegetative illnesses, deprofessionalisation, different types of professional and personal deformations.

The presented results do not cover all aspects of the issue. It is planned to study the relationship between intensive daily stress and indicators of pedagogue's profes-

\section{REFERENCES}

1. Baiguzhin, P. A. (2012). Sposoby optimizatsii napriazhennosti umstvennogo truda kak faktor professionalnogo stressa (obzor) [Methods of optimization of brain work tension as a factor of occupational stress (review)]. Vestnik Cheliabinskogo gosudarstvennogo pedagogicheskogo universiteta - Bulletin of Cheliabinsk state pedagogical university, 3, 378-393. Chelyabinsk: CSPU, Retrieved from: ftp://ftp.cspu.ru/upload/archivvestnik/2012/2012_3.pdf [in Russian].

2. Vasserman, L. I., Berebin, M. A. (1997). Faktory riska psikhicheskoi dezadaptatsii u pedagogov massovykh shkol [Risk factors of teachers' psychic disadaptation]. Saint-Petersburg: Publishing house of Psychoneurologic V. M. Bekhterev institute [in Russian].

3. Gandziuk, V. A. (2014). Analiz zakhvoriuvanosti na ishemichnu khvorobu sertsia $\mathrm{v}$ Ukraini [Analysis of ischemic heart disease rate in Ukraine]. Ukrainskyi kardiolohichnyi zhurnal - Ukrainian Journal of Cardiology, 3, 45-52 [in Ukrainian].

4. Dziuba, T. M. (2016). Psykhometrychnyi analiz rozrobky y aprobatsii metodyky «Ryzyky profesiinoho zdorovia» [Psychometric analysis of development and approbation of technique "Risks of occupational health"]. Visnyk KhNPU imeni H.S. Skovorody. Psykholohiia Bulletin of KNPU named after H. S. Skovoroda, 53, 4756. Kharkiv: G. S. Skovoroda Kharkiv national pedagogical university [in Ukrainian]

5. Leonova, A. B., Kuznetsova, A. S. (1993). Psikhoprofilaktika stressov [Psychoprophylaxis of stress]. Moscow: Moscow university publishing house [in Russian].

6. Maliavskaia, S. I. (2010). Pediatricheskii meta-

\section{ЛІТЕРАТУРА}

1. Байгужин П. А. Способы оптимизации напряженности умственного труда как фактор профессионального стресса (обзор) / П. А. Байгужин // Вестник Челябинского государственного педагогического университета. - 2012. - № 3.- С. 378-393. Режим доступа: ftp://ftp.cspu.ru/upload/archivvestnik/2012/2012_3.pdf

2. Вассерман Л. И., Беребин М. А. Факторы риска психической дезадаптации у педагогов массовых школ. Пособие для врачей и психологов / Л. И. Вассерман, М. А. Беребин. - СПб., 1997. - 52 с.

3. Гандзюк В. А. Аналіз захворюваності на ішемічну хворобу серця в Україні / В. А. Гандзюк // Український кардіологічний журнал. - № 3. - 2014. C. $45-52$. sional self-attitude. The scientific literature review and observations let us make an assumption that intensive daily stress causes unconformity which provokes internal proneness to conflicts feeling of inferiority. Objective inability to eliminate stress factors of professional environment creates a basis for professional deformation and marginalism.

bolicheskii sindrom: sostoianie vysokogo riska [Pediatric metabolic syndrome: state of high risk]. Pediatriia - Pediatric, (Vol. 89), 4, 119-122 [in Russian].

7. Mitina, L. M. (2004). Psikhologiia truda i professionalnogo razvitiia uchitelia [Psychology of labor and pedagogue's occupational development]. Moscow: Academy [in Russian].

8. Rudenskii, E. V. (1999). Sotsialno-psikhologicheskie deformatsii lichnosti uchitelia [Socio-psychological deformations of pedagogue's identity]. Mir psikhologii - The world of psychology, 2, 169-174 [in Russian].

9. Maksymenko, S. D., Karamushka, L. M., Zaichykova, T. V. (2004). Syndrom "profesiinoho vyhorannia» ta profesiina kariera pratsivnykiv osvitnikh orhanizatsii: genderni aspekty [Syndrome of "professional burn-out" and professional carrier of educational organization employees: gender aspects]. Kyiv: Millennium [in Ukrainian].

10. Turenko, E. A. (2010). Osobennosti sovladaniia uchitelei s professionalnym stressom [Specifics of pedagogues' coping with occupational stress]. Vestnik SanktPeterburgskogo gosudarstvennogo universiteta - Bulletin of Saint-Petersburg university, 4, 186-192 [in Russian].

11. Kharchenko, S. V. (2010). Teoretykometodolohichni zasady doslidzhennia fenomenu stresu ta pratsezdatnosti [Theoretical and methodological basics of studying of stress phenomena and work efficiency]. S.V. Kharchenko Problemy zahalnoi ta pedahohichnoi psykholohii - Problems of General and Educational Psychology (Vol. 12). Kyiv: Collection of studies of NAPS G. S. Kostyuk psychology [in Ukrainian].

4. Дзюба Т. М. Психометричний аналіз розробки й апробації методики «Ризики професійного здоров'я» / Т. М. Дзюба // Вісник ХНПУ імені Г.С. Сковороди. Психологія. Вип. 53. - Х.: ХНПУ, 2016. С. 47-56.

5. Леонова А. Б., Кузнецова А. С. Психопрофилактика стрессов / А. Б. Леонова, А. С. Кузнецова. - М.: Изд-во Моск. ун-та, 1993. - 123 с.

6. Малявская С. И. Педиатрический метаболический синдром: состояние высокого риска / С. И. Малявская // Педиатрия. - 2010. - Т. 89, № 4. - С. 119-122.

7. Митина Л. М. Психология труда и профессионального развития учителя / Л. М. Митина. - М.: Академия, 2004. - 320 c.
8. Руденский
E. B.
Социально- 
психологические деформации личности учителя / Е. В. Руденский // Мир психологии. - 1999. - № 2. C. 169-174.

9. Синдром «професійного вигорання» та професійна кар'єра працівників освітніх організацій: гендерні аспекти: Навч. посіб. для студ. вищ. навч. закл. та слухачів ін-тів післядиплом. освіти / За гаук. ред. С.Д. Максименка, Л.М. Карамушки, Т. В. Зайчикової. - К.: Міленіум, 2004. - 264 с.

10. Туренко Е. А. Особенности совладания учи- телей с профессиональным стрессом / Е. А. Туренко. Вестник Санкт-Петербургского государственного университета. - Сер. 12. - 2010. - Вып. 4. - С. 186-192.

11. Харченко С. В. Теоретико-методологічні засади дослідження феномену стресу та працездатності / С. В. Харченко // Проблеми загальної та педагогічної психології: Збірник наукових праць інституту психології ім. Г.С.Костюка НАПНУ. - 2010, т. ХІІ, ч.2. - С. 358-366.

Тетяна Михайлівна Дзюба, кандидат психологічних наук, доцент кафедри загальної, вікової та практичної психологї, Полтавський національний педагогічний університет імені В. Г. Короленка, вул. Остроградського, 2, м. Полтава, Украйна

\section{ПРОБЛЕМА ВПЛИВУ ІНТЕНСИВНОГО ПОВСЯКДЕННОГО СТРЕСУ НА ПРОФЕСІЙНЕ ЗДОРОВ'Я ПЕДАГОГА}

У статті визначено специфічні параметри впливу інтенсивного повсякденного стресу на професійне здоров'я педагога. Проаналізовано низку значущих кореляційних взаємозв’язків між виявленими параметрами. Підкреслено, що основні хронічні захворювання сьогодення виникають на тлі емоційних переживань, гострого та хронічного стресу. На основі визначених взаємозв'язків розглянуто інтенсивний повсякденний стрес як специфічну ознаку професійно-педагогічної діяльності, що за певних умов виступає ризиком емоційного вигорання і втрати професійного здоров'я працівника. Зазначено, що інтенсивний повсякденний стрес в умовах професійно-педагогічній діяльності порушує адаптаційні ресурси, формуючи шкідливі ефекти професійно-особистісної деформації педагога (когнітивні, емоційні, поведінкові) та негативно позначається на зміні його настрою і професійній копінгповедінці. Професійний стрес активізує майже весь репертуар копінг-стратегій педагога, але в ситуації тривалого інтенсивного стресу спостерігається збільшення частоти використання пасивних («уникання», «обережні дії», «прийняття») i просоціальних («пошук соціальної підтримки») копінг-стратегій. Недостатність використання стратегій «здорового» активного копінгу, спрямованого на конструктивне перетворення ситуації, та переважання пасивних стратегій призводить до того, що професійний стрес набуває хронічного характеру, а в діях і вчинках більше виявляється асоціальна поведінка, що пов'язана з порушенням моральних норм у ситуаціях професійного спілкування. В умовах довготривалого інтенсивного стресу виявлені стратегії можуть розглядатися як поведінкові фактори ризику професійного здоров’я працівника.

Ключові слова: інтенсивний повсякденний стрес, професійне здоров'я, адаптаційні ресурси працівника, копінг-стратегії, шкідливі ефекти професійно-особистісної деформації, емоційне вигорання, поведінкові фактори ризику професійного здоров’я працівника.

Reviewed by Doctor of Psychology, prof. S. Yalanska

Submitted on February, 3, 2017 